\title{
Economic dimension of engineering and construction in Russian orthodox temple architecture
}

\author{
Maria Bovsunovskaya ${ }^{1, *}$ and Ivan Saltykov ${ }^{1}$ \\ ${ }^{1}$ Moscow State University of Civil Engineering, Yaroslavskoye shosse, 26, Moscow, 129337, Russia
}

\begin{abstract}
Economic dimension of engineering and construction in Russian orthodox temple architecture (reliable determination of church construction estimate cost and it's optimization) is in the best interest of engineering companies, the Russian Orthodox Church, state authorities and potential investors as basis for assessment of investment, cost control, cost saving in temple complex construction. The article gives methodological aspects of cost estimate determination in temple architecture, synthesizes cost expenditures for temple construction, proposes and analyses cost-saving solutions.
\end{abstract}

\section{Introduction}

Reverential attitude to religion with orthodox temple architecture is the basis of Russian national and cultural identity. In seventy-year Soviet-era there were negation of orthodox religion and suspension of native architectural tradition in temple construction. Over the last years orthodox temple construction is on the rise. With all new architectural trends and abundance of expressive project solutions modern temple architecture accumulates rich Russian orthodox history and is still canonical and traditional [1].

Modern churches are built under orthodox canons with expensive materials and technologies, but as a rule the construction is being funded by limited offertory means. In this regard reliable determination of estimate cost as early as the planning stage is in great demand. The aim of cost determination is assessment of investment, cost control, cost saving in temple complex construction. The determination and optimization of temple construction cost are attractive to the building owner (including the Russian Orthodox Church for budget determination), to the architects (for correcting project concept according it's cost), to the state authorities (for project popularization and attracting investment in the region), to the potential investors (for cost control).

\section{Materials and Methods}

Costing methods in temple architecture at the different project stages are based on general rules of estimating cost for other construction projects in Russian Federation.

\footnotetext{
*Corresponding author: saltmasha@mail.ru
} 
The main methods of construction costing are input method, index method and analog method. The principle of input method consists in calculation of three cost groups: materials, vehicles and machinery, labor cost. It is in the use in pricing under low volume construction (small church, chapel). Under considerable volume construction, difficult project solutions and at the opening phase the input method is irrelevant, because of its labor intensity.

The index method (using the unit rates for construction) is irrelevant at the opening project phase considering the lack of developed project documentation, but is in the use during contract process and under the construction. At the opening project stage it's worth paying attention to analog and consolidated cost index method for the forward estimate [2, 3]. Before estimating the composition of consolidated costs has to be checked and corrected in the case of need. Such method enables you to come up with approximative budget within a short period of time, at the same time it doesn't consider entirely all constructive and spaceplanning solutions. The precision of this method is about $20-30 \%$. The cost data come from national cost regulations and commercial cost books, data basis of project companies and the Russian Orthodox Church. Designing cost is calculated by three generally known methods. Because of accuracy, speed and simplicity, the method of physical indicator is in great demand. The complexity consists in the lack of cost standards in base price books for temple complexes at the federal and regional levels. That's why it is possible to determine designing cost according to the Moscow prices for religious building and correct it with special regional indexes. The second method "in percent of construction cost" is useful at the opening project stage and is careless owing to calculating error in construction cost. The last method is devoted to estimation of working hours, it is laborious and rather hard.

\section{Results}

In the course of investigations cost estimate determinate formula has been recommended. The formula is in great demand for cost estimates in temple architecture and includes cost items of construction cost estimate summary for any projects. The cost estimate of temple complex $\left(\mathrm{C}_{\text {t.c. }}\right)$ involves designing and building expenditures for all temple complex erections (formula 1).

$$
\begin{gathered}
\text { Ct. } .=\left(\text { Cch.c. }+\sum_{i=1}^{n} \text { Cc. } i\right)+ \\
\text { Pl. }+ \text { Cut. }+ \text { Cs. im. }+ \text { Cc. }+\left(\text { Cch.d.s. w. }+\sum_{i=1}^{n} \text { Cd.s.w. } i\right)+\text { S.e. }
\end{gathered}
$$

where $\mathrm{C}_{\text {ch.с. и }} \sum_{i=1}^{n} C$ c. $i$ - cost of building of the church and all other erections of the temple complex;

$\mathrm{P}_{1 .}$ - price for land (if it is necessary);

$\mathrm{C}_{\mathrm{ut}}-$ cost of off-site utilities (if it is necessary);

$\mathrm{C}_{\text {s.im. }}$ - costs for site improvement;

$\mathrm{C}_{\text {c. }}$ - customer service charges;

$\mathrm{C}_{\text {d.s.w. и }} \sum_{i=1}^{n} C d . s . w . i-$ cost for design and survey work of the church and all other erections of the temple complex;

S.e. - sundry expenses.

It is important to separate new construction from reconstruction in old temple orthodox complex, because the cost of remodeling and reconstruction has to be estimated additionally.

There is the difference between cost estimates of freestanding temple buildings and infill temple building. In the case of infill temple building the parts of the construction are estimated singly according it's function with consolidated cost indexes, the costs are summarized with the special coefficients [4].

The expenditures for interior decoration of the church (fresco, painting, iconostasis, furniture, light) are estimated additionally. 
As a rule, the temple construction cost is rather expensive for investors. It's a matter of simultaneous two architect aims: to preserve canonical image and to use salient features of contemporary architecture. At the same time the cost optimization by it's minimization in any way is unacceptable. Cost-saving solutions in temple orthodox architecture may have both positive and negative effects in long-term prospects (table 1).

Table 1. Cost-saving solutions in designing and construction of temple complex in Russian Federation.

\begin{tabular}{|c|c|c|c|}
\hline \multirow[t]{2}{*}{ No } & \multirow[t]{2}{*}{ Cost-saving solution } & \multicolumn{2}{|c|}{ Effect } \\
\hline & & Positive & Negative \\
\hline 1. & Modularity principle & $\begin{array}{l}\text { Analogue of erector set. } \\
\text { Main elements may be } \\
\text { changed: size, aisles, porch, } \\
\text { steeple, cupola, etc.) (Fig.1) }\end{array}$ & $\begin{array}{l}\text { It has not been used and has been } \\
\text { changed by method of standard } \\
\text { projects. }\end{array}$ \\
\hline 2. & $\begin{array}{l}\text { Standard projects } \\
\text { (according to the } \\
\text { Program "200 } \\
\text { Temples" in } \\
\text { Moscow) }\end{array}$ & $\begin{array}{l}\text { Seven main temple types } \\
\text { with finished project } \\
\text { documentation }\end{array}$ & $\begin{array}{l}\text { The special standard extended } \\
\text { products. There are no special } \\
\text { manufacturing plants. }\end{array}$ \\
\hline 3. & $\begin{array}{l}\text { Imitation of previous } \\
\text { projects }\end{array}$ & Time and cost saving & $\begin{array}{l}\text { Mechanical compilation of } \\
\text { historical styles of old periods }\end{array}$ \\
\hline 4. & $\begin{array}{l}\text { Application of low- } \\
\text { cost materials in } \\
\text { construction }\end{array}$ & $\begin{array}{l}\text { Imitation of expensive forms } \\
\text { and materials. For example, } \\
\text { using dolomite for granite. }\end{array}$ & $\begin{array}{l}\text { Unaesthetic elevation of } \\
\text { building, strength reduction, } \\
\text { operating life reduction. }\end{array}$ \\
\hline 5. & $\begin{array}{l}\text { Rational choice of } \\
\text { construction materials }\end{array}$ & $\begin{array}{l}\text { Durability and lasting quality } \\
\text { of building }\end{array}$ & Expensive materials \\
\hline 6. & $\begin{array}{l}\text { Functionality of } \\
\text { temple interior space }\end{array}$ & $\begin{array}{l}\text { Excluding lack of temple } \\
\text { space (fig.2) }\end{array}$ & $\begin{array}{l}\text { Some churches doesn't have full } \\
\text { porch. }\end{array}$ \\
\hline 7. & $\begin{array}{l}\text { Application of } \\
\text { rational space- } \\
\text { planning decisions }\end{array}$ & $\begin{array}{l}\text { Non-admission of square and } \\
\text { volume increase for } \\
\text { calculated temple capacity }\end{array}$ & $\begin{array}{l}\text { Some temple types are } \\
\text { uneconomic because of additory } \\
\text { room volume (the example of } \\
\text { such old church - fig. } 3 \text { ) }\end{array}$ \\
\hline 8. & $\begin{array}{l}\text { Use of free } \\
\text { ventilation }\end{array}$ & $\begin{array}{l}\text { Economy of one-time and } \\
\text { working expenditures }\end{array}$ & Project complexity \\
\hline 9. & $\begin{array}{l}\text { Multistage } \\
\text { construction }\end{array}$ & $\begin{array}{l}\text { Speed-up and cheapening of } \\
\text { construction }\end{array}$ & $\begin{array}{l}\text { Difficult managing construction } \\
\text { process }\end{array}$ \\
\hline 10. & $\begin{array}{l}\text { Deferment of interior } \\
\text { temple beautification }\end{array}$ & $\begin{array}{l}\text { Installation of temporary } \\
\text { elements }\end{array}$ & Simplicity of temple exterior \\
\hline
\end{tabular}

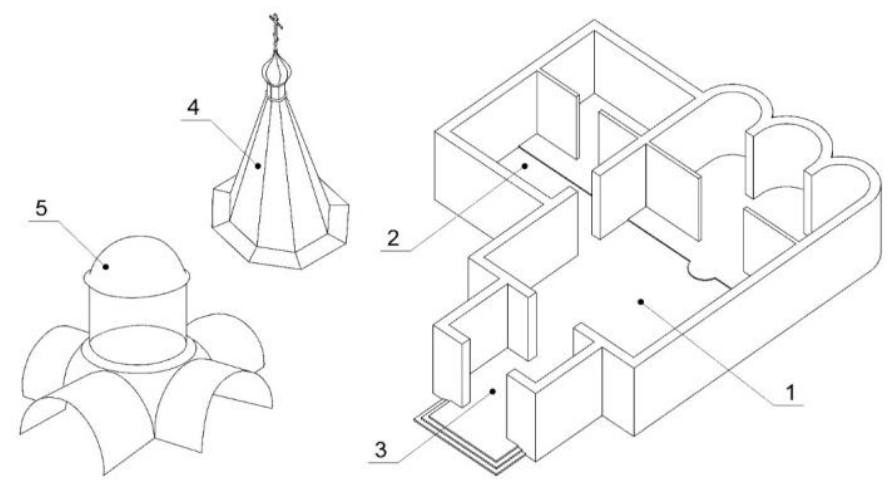

Fig. 1. Main temple elements: 1 - temple space, 2 - aisle, 3 - porch, 4 - steeple, 5 - cupola. 


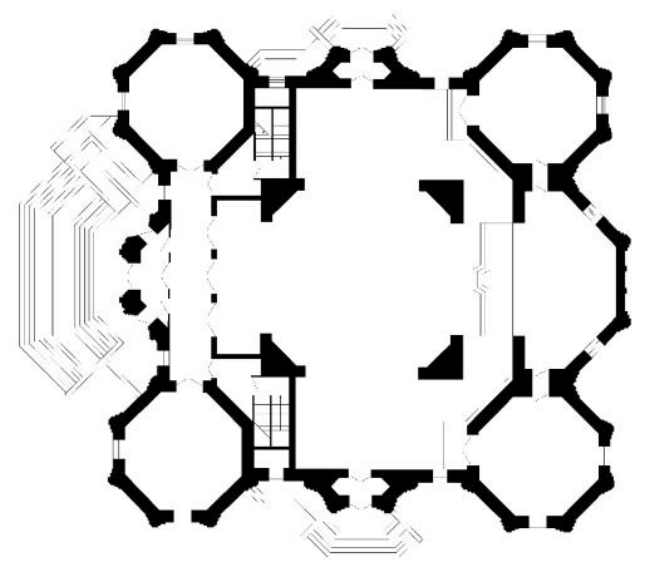

Fig. 2. Example of modern spacious church.

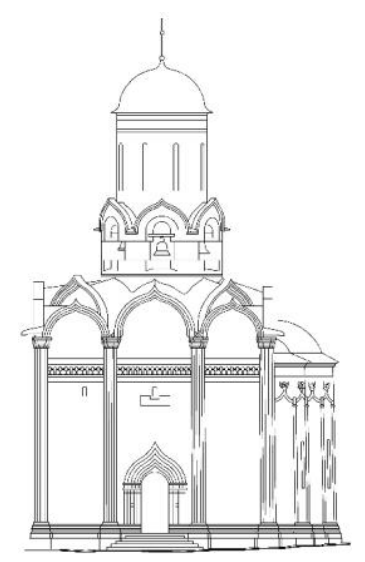

Fig. 3. Example of old church "The Descent of the Holy Ghost upon the Apostles" in the Trinity Lavra of St. Sergius.

\section{Discussion}

Practically, the reliable determination of temple cost estimate is difficult in consequence of cost peculiarities for temple projects:

$\checkmark \quad$ Region and special features [5, 6].

Region climate pattern has to be considered in the choice of optimal constructive decision. The project has to include expenditures for construction and for potential operational cycle: heating, lighting and perflation.

$\checkmark \quad$ Variety of project solutions [7].

The temple orthodox architecture is canonical and traditional, and has liturgical aim. There is union of traditions and innovation in designing.

$\checkmark \quad$ Engineering of the churches as part of the temple complex [8].

The temple complex cost may include the expenditures for church, bell-tower, delubrum, chapel, parsonage, hotel, accommodation, Sunday school, library, hospital, frater house, church market, workshops and etc.

$\checkmark \quad$ High cost of temple materials and carcass. 
The high materials cost can be attributed to both long operating cycle and esthetic significance of the church. Among the materials there are rare and imported (different species of wood, stone). Expensive element are cupolas, roods, doors.

$\checkmark \quad$ New construction and reconstruction of temple complexes are often connected.

Reconstruction of temple complexes needs the special knowledge, it is important to union old and new erections in one composition.

$\checkmark \quad$ High cost of the interior temple space.

The new church needs heavy expenses for interior decoration (fresco, painting, iconostasis, furniture, light).

Atypical sources of financing.

The main sources of temple construction financing are charity of individuals and companies, investment of the Russian Orthodox Church. Sometimes the churches have been built by construction companies during building modern urban district. Federal or regional investment are lacking.

\section{Conclusions}

All mentioned peculiarities and cost-saving solutions impact on labor intensity of estimating process and cost value in temple orthodox architecture. During estimates it is necessary to be respectful of the engineering church, to take into consideration it's long operational cycle and it's importance for church members and officers. The specificity of cost estimates in temple architecture is dictated by essentiality to put a price on priceless heritage of future generations.

\section{References}

1. M.A. Men, Development of temple architecture in Russia. Image of orthodox church: from history to modernity, Talk abstracts of lecture

2. V.S. Bashkatov, E.V. Myshinskaya, Contractual relations in Russian Federation 5(128), 52-62 (2012)

3. E.D. Veselova, E.I. Rychkova, A.E. Stasishina, A.I. Norkina, News of St. Petersburg's railway university $3,157-161$ (2014)

4. Orthodox temple. In three toms. Tom 2. Orthodox churches and complexes: book for engineering and construction (AHC «Arhhram», Moscow, 2003)

5. V. Kankhva, E3S Web of Conferences 33, 01036 https://doi.org/10.1051/e3sconf/20183301036

6. S. Uvarova, V. Vlasenko, A. Burkeev, L. Myshovskaya, O. Kuzina, E3S Web of Conferences 33, 03022 (2018) https://doi.org/10.1051/e3sconf/20183303022

7. M. Kesler, Contest results "Project of orthodox temple with capacity 300, 600, 900 patrons", http://kesler.ortox.ru/2016/02/04/itogi-konkursa-proekt-pravoslavnogoxrama-vmestimostyu-300-600-900-chelovek-s-prixodskim-kompleksom/

8. Code Design 31-103-99. Buildings and temple orthodox complexes 